\section{Mammals and Man}

REFERENCE was made in Nature of Feb. 22, to the temporary exhibition "Mammals and Man" at the National Museum of Wales, and to the lack of references in the guide-book "to modern developments such as the varied and most important uses of whale oil, the increasing resort to mammal products in biological therapy", etc. Mr. Colin Matheson, curator of the Museum, informs us that a well-known British firm has provided samples of vitamin A concentrate prepared from whale liver, hydrogenated whale oils of various melting points, spermaceti, and other important cetacean products, for the exhibition. The exhibit was unfortunately delayed in transit owing to war conditions, and did not arrive until the guide-book was in the press.

\section{William Withering}

MARCH 17 marks the bicentenary of the birth of Dr. William Withering, who was celebrated alike as physician, botanist and mineralogist. He was born at Wellington, Shropshire, the only son of Edmund Withering, a surgeon. He received his medical education at Edinburgh, where he qualified in 1776 with a thesis on "Malignant Putrid Sore Throat", which he afterwards identified with a severe form of scarlet fever. After a visit to Paris, where he attended a meeting of the Royal Academy of Sciences, he settled in Stafford in 1767 and first began to collect flowers. In 1775 he moved to Birmingham, where he soon acquired a lucrative practice, and the following year published his most important work entitled "A Botanical Arrangement of all the Vegetables naturally growing in Great Britain". The book went through seven editions, and an abbreviated version, of which three were published, by W. Macgillivray, first appeared in 1830.

At Birmingham Withering became a member of the Lunar Society, so called from its monthly meetings, and made there the acquaintance of Priestley, Watt and other distinguished men of science. In 1779 he published his "Account of the Scarlet Fever and Sore Throat, particularly as it appeared in 1778-1779", which is an important contribution to epidemiology and clinical medicine. In 1785, when he was elected F.R.S., appeared his classical paper on the foxglove, the value of which in dropsy he had learnt from an old woman in Shropshire, an excellent example of a folk-lore remedy being adopted by the orthodox profession. His interest in mineralogy is shown by the several contributions to the Transactions of the Royal Society. $\mathrm{He}$ also translated and annotated a treatise entitled "Outlines of Mineralogy" by Bergman "(1783). During a visit to Lisbon in 1795 he wrote a paper on "A Chymical Analysis of the Water at Caldas da Rainha, in Portugal", which he presented to the Royal Academy at Lisbon, for which he was admitted a foreign corresponding member.

His name has been given to the mineral known as 'witherite', consisting of barium carbonate, which he recognized to be distinct from baryta, as well as to the genus of Solanacea (Witheringia Solanacea). In
1792 he contributed a paper entitled "A Method of preserving Fungi, ascertained by Chymical Experiments" to the Transactions of the Linnean Society, of which he was elected a fellow the following year. He died on October 6, 1799, and was buried at Edgbaston, where the church contains his monument with a represensation of a foxglove on the right and of Witheringia Solanacea on the left.

\section{Announcements}

THE following promotions and transfers have recently been made in the Colonial Service: J. D. Broatch (agricultural superintendent), senior agricultural superintendent, Gold Coast; D. H. Brown (agricultural officer), senior agricultural officer, Nigeria; T. A. Buckley (chemist), senior chemist, Malaya; K. T. Hartley (chemist), senior chemist, Nigeria; L. J. Packham (agricultural superintendent), senior agricultural superintendent, Gold Coast; L. S. Davis (assistant Government analyst), Government chemist, Trinidad; E. J. Strugnell (senior assistant conservator), conservator of forests, Malaya ; Dr. C. M. Tattam (geologist), senior geologist, Nigeria.

Messrs. Outver and Boyd Ltd., Tweeddale Court, Edinburgh, and 98 Great Russell Street, London, W.C., have been appointed publishers to the Royal Society of Edinburgh. Copies of previous issues of the Transactions and Proceedings and of all future publications of the Society will now be supplied by this firm.

The Canberra Experiment Station of the Plant Industry Division of the Australian Council for Scientific and Industrial Research is to be removed to a new area to the north of the capital, about four miles from the laboratories at Black Mountain. The area is eight hundred acres, of which six hundred are red and grey loams and the remainder rather lighter. The site is ideal for experimental work, and it should be possible in time to develop on it a first. class investigation centre.

ACCORDING to the seventeenth annual report of the Ella Sachs Plotz Foundation for the Advancement of Scientific Investigation, eighty-one applications for grants were received by the trustees, and twenty-three grants were made. In the seventeen years of its existence the Foundation has made three hundred and ninety-four grants, which have been distributed to investigators in most countries of the world. For the present, researches are being favoured that are directed towards the solution of problems in medicine and surgery or in branches of science bearing on medicine and surgery. Grants may be used for the purchase of apparatus and supplies that are needed for special investigations. The maximum grant will usually be less than 500 dollars. Applications for grants to be beld during the year 1941-42 must be in the hands of the Executive Committee before April 1941. Applications should be sent to Dr. Joseph C. Aub, Collis P. Huntington Memorial Hospital, 695 Huntington Avenue, Boston, Massachusetts, U.S.A. 